DEMOGRAPHIC RESEARCH

VOLUME 30, ARTICLE 15, PAGES 429-464

PUBLISHED 11 FEBRUARY 2014

http://www.demographic-research.org/Volumes/Vol30/15/

DOI: 10.4054/DemRes.2014.30.15

Research Article

\title{
Social class and net fertility before, during, and after the demographic transition: \\ A micro-level analysis of Sweden 1880-1970
}

\section{Martin Dribe}

\section{Francesco Scalone}

This publication is part of the Special Collection on "Socioeconomic status and fertility before, during and after the demographic transition”, organized by Guest Editors Martin Dribe, Michel Oris, and Lucia Pozzi.

๑ 2014 Martin Dribe and Francesco Scalone.

This open-access work is published under the terms of the Creative Commons Attribution NonCommercial License 2.0 Germany, which permits use, reproduction \& distribution in any medium for non-commercial purposes, provided the original author(s) and source are given credit.

See http:// creativecommons.org/licenses/by-nc/2.0/de/ 


\section{Table of Contents}

1 Introduction $\quad 430$

$2 \quad$ Background $\quad 431$

3 Data 437

4 Methods 441

$5 \quad$ Net fertility by socioeconomic status 442

$6 \quad$ Regression results $\quad 444$

$7 \quad$ Conclusion $\quad 450$

$8 \quad$ Acknowledgements 453

References $\quad 454$

Appendix. A comparison of CWR and mortality-adjusted CWR 461 


\title{
Social class and net fertility before, during, and after the demographic transition: A micro-level analysis of Sweden 1880-1970
}

\author{
Martin Dribe ${ }^{1}$ \\ Francesco Scalone ${ }^{2}$
}

\begin{abstract}
BACKGROUND

Although demographers have long been interested in studying the historical fertility transition, there is still a lack of knowledge about disaggregated patterns. Identifying these patterns could help us to better understand the mechanisms behind the transition.
\end{abstract}

\section{OBJECTIVE}

The aim of this paper is to explore social class differentials in fertility before, during, and after the fertility decline, in order to test hypotheses regarding a reversal of class differences during the transition.

\section{METHOD}

We use micro-level census data for Sweden 1880, 1890, 1900, 1960, and 1970 with individual-level information on occupation, which is used to measure class. Poisson regressions with parish-level fixed effects enable us to carefully control spatial heterogeneity in measuring class differences in net fertility (child-woman ratios).

\section{RESULTS}

The relative differences were about as large in the early phases of the transition as they were in the 1960s. The fertility levels of the high-fertility classes were about $40 \%$ higher than those of the low-fertility classes. In the early phases of the decline, the upper and middle classes had much lower net fertility than lower skilled workers, who had the highest fertility levels. However, there was no clear gradient from the highest to the lowest socioeconomic status. Instead, it appears that the upper and middle classes had low fertility levels, while the fertility levels of the remaining groups were unchanged, and therefore remained relatively high. In the 1960s, members of the

\footnotetext{
${ }^{1}$ Centre for Economic Demography, Lund University, Sweden. E-Mail: Martin.Dribe@ekh.lu.se.

${ }^{2}$ Department of Statistical Sciences, University of Bologna, Italy. E-Mail: Francesco.Scalone@unibo.it.
} 
middle class had the lowest fertility levels, while farmers and rural laborers had the highest fertility levels.

\section{CONCLUSIONS}

The results only partly confirm the assumption that there was a reversal in class differences in the demographic transition. Class was found to be important, but the pattern was not characterized by a simple gradient. Moreover, spatial heterogeneity was shown to explain about half of the observed differences between classes. The observed pattern suggests that the fertility transition can be attributed to both innovationdiffusion and the adjustment to new socioeconomic conditions.

\section{Introduction}

The decline of fertility in the demographic transition has been a major theme in historical demography for some time. Much of the literature focusing on the demographic aspects of the decline has sought to chart the process without actually explaining it. Other studies have offered explanations for the decline mainly at the macro level, identifying either innovation or adjustment processes as the main causal agents. Scholars have shown less interest in examining disaggregated patterns using micro-level analyses.

One of the main issues that arises in discussions of the fertility decline is the extent to which fertility levels differ according to socioeconomic status, and how these differences evolved over the fertility transition. Most demographers appear to agree that having higher social status was associated with having higher fertility prior to the transition, but that this situation reversed during the transition, or even before it occurred (Livi-Bacci 1986; Skirbekk 2008). While it is therefore often assumed that higher social groups were forerunners in the decline (Haines 1992; Livi-Bacci 1986), the question of whether the change happened because new incentives were affecting the elite groups first (adjustment), or if it came about as a result of a diffusion of new ideas first adopted in these high-status groups (innovation), remains unresolved (see Haines 1992).

As some of the differences in fertility levels between socioeconomic groups may have also been related to spatial differences in socioeconomic structure, rather than to social status as such (Garrett et al. 2001); it is essential that researchers control for the spatial aspect when analyzing socioeconomic stratification and fertility in national populations (see also Szreter 1996).

The aim of this article is to study the socioeconomic differentials in fertility before, during, and after the transition. We use data from the Swedish censuses of 1880, 1890, 
1900, 1960, and 1970. As these data cover the entire population (about five to seven million individuals in each census), we can investigate the socioeconomic pattern in considerable detail, while controlling for spatial heterogeneity.

The main advantage of using census data is that, because of the broad coverage provided by the census, we are able study fertility differentials by socioeconomic status across space, without having to deal with the problems associated with using a small sample size. The data also offer quite detailed information on occupation, which allows us to classify individuals using standard class schemes. The main disadvantage of using historical census data $(1880,1890,1900)$ is that they do not contain information on births by the age of the woman. Thus, when computing conventional fertility rates, we have to rely on indirect measures, such as child-woman ratios. However, previous analysis has shown that these measures are quite accurate in depicting socioeconomic fertility differentials, even in a context of moderately high mortality (Scalone and Dribe 2012). The data are also lacking in other variables that might have helped to explain possible class differences. Hence, the main focus of our analysis will be on how class differences evolved over time, but our discussion of the possible explanations for these differences will be more tentative.

In the first part of the paper, we provide some background information on the fertility transition in Sweden, and summarize the main analytical framework for studying socioeconomic differences in reproductive behavior. We then describe the census data, provide some indirect estimates of fertility by socioeconomic status, and present the main empirical analysis.

\section{Background}

When we first look at the development of fertility in Sweden over a longer time span (see Figure 1), it is clear that the long-term level of fertility was quite stable until the last quarter of the 19th century: i.e., at between four and five children per woman, or around eight children per married woman. Beginning around 1880, period fertility declined steadily until the beginning of the 1930s, when it started to increase again. Between 1880 and 1900, the decrease was modest, but accelerated rapidly thereafter. This period between 1880 and 1930 marks the decline in Swedish fertility. It constitutes an important phase of the demographic transition, which took place about 100 years after infant mortality started its continuous decline (see, e.g., Hofsten and Lundström 1976). Thus, when we look at the cohort fertility pattern, it is apparent that the decline started with the cohorts born around 1850, who would have been in their prime childbearing ages in the early 1880s. 
Figure 1: $\quad$ Fertility rates in Sweden 1800-1995

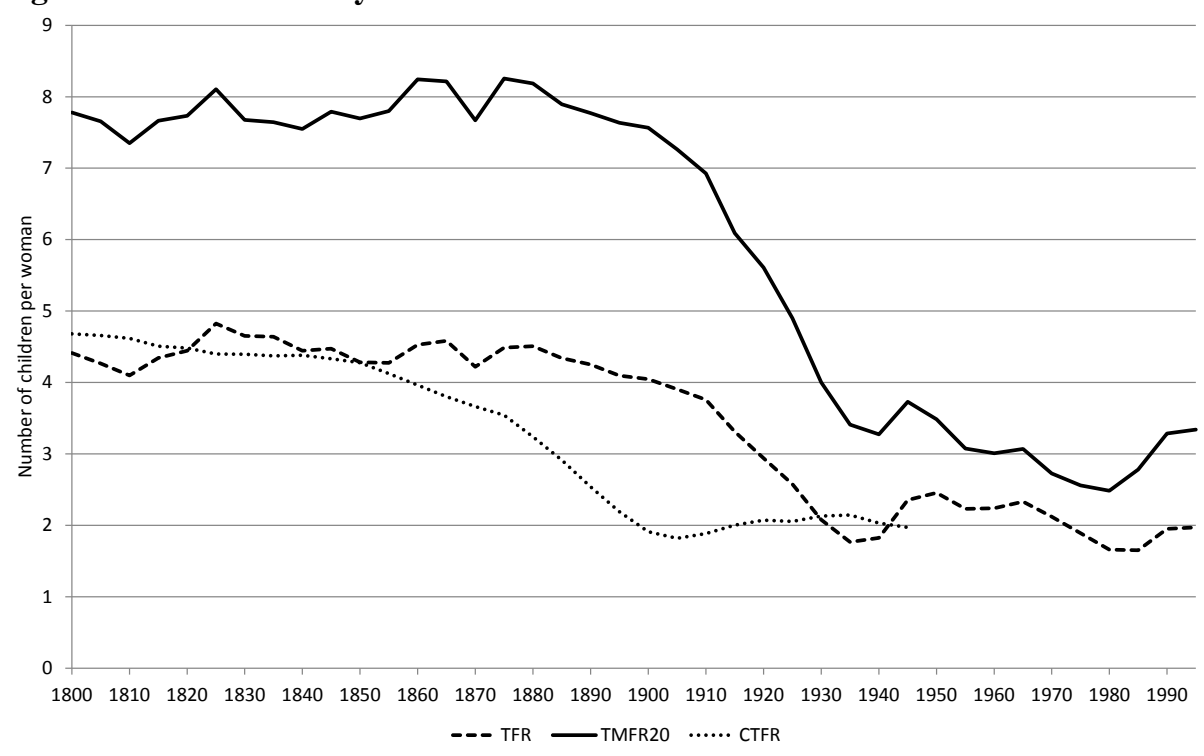

Source: Statistics Sweden (1999).

Note: CTFR is the accumulated number of children at age 50 . X-axis refers to year of birth for cohort fertility.

We can also see that marital fertility followed closely total fertility. This observation is in line with the well-established findings of previous research on the European fertility transition, which showed that the decline is mainly attributable to a decrease in marital fertility rather than to changes in nuptiality (Carlsson 1966; Coale and Watkins 1986). The fertility of the oldest age groups decreased the fastest, even though the decline started in all of the age groups over 25 at about the same time (see Dribe 2009). In terms of the relative contributions of different age groups to the fertility decline, research has indicated that women of the prime childbearing ages (25-40) contributed the most. Immediately before the fertility transition, most of the counties in Sweden showed no signs of parity-specific control; this implies that, with a few exceptions, the fertility pattern in pre-transitional Sweden was natural (Henry 1961). Nonetheless, the levels of marital fertility varied considerably between the counties, and these differences persisted during the transition, and even widened in relative terms (Dribe 2009).

Previous studies have tended to support the assumption that the fertility decline could be linked to broad socioeconomic changes that took place in the late 19th and early 20th centuries, following the transition from an agricultural to an industrial 
economy (see Dribe 2009). This transition was associated with sustained reductions in mortality, higher levels of urbanization, the expansion of education, and increased participation in market work by women. Yet the question of how these changes affected different socioeconomic groups has not been fully answered.

Looking at the fertility decline in France, Germany, Britain, Norway, and the United States, Haines (1992) showed that the socioeconomic differentials, as measured by occupation, generally widened during the transition. With the exception of France, the fertility decline in all of these countries was led by the middle and upper classes, while the agrarian populations were slower to change. The question is whether this pattern was the result of socioeconomic changes which first affected the upper and middle classes, and did not reach the lower classes until later; or whether it was part of an older pattern in which innovation diffused from the upper to the lower social strata.

According to Livi-Bacci (1986), European elite groups often led the fertility transition, as fertility decreased among these groups much earlier than it did among the general population. He also argued that the early decline among these groups was connected at least in part to the fact that they tended to live in cities. But he was uncertain about whether the socioeconomic and cultural characteristics of the urban environment created the conditions for fertility change, or whether the elite groups had more specific characteristics which caused them to have fewer children.

Evidence from other studies has pointed in the same direction. High status families in pre-transitional Sicily had considerably more surviving children than low status families, largely because of a combination of mortality and higher marital fertility (shorter birth intervals) (Schneider and Schneider 1996). During the transition, the higher social groups were the first to reduce their fertility, with the poorer groups lagging behind. However, looking at Stockholm in the period immediately after the fertility decline in the 1930s, Edin and Hutchinson (1935) found higher marital fertility levels among the higher status groups, regardless of whether the status was measured by occupation, wealth, or education. It remains unclear whether these results only apply to the capital city, or can be generalized to the country as a whole. In pre-transitional Norway, however, the socioeconomic fertility differentials were quite modest, as the fertility rate was somewhat higher among the group with the highest status (but it is unclear whether the difference was statistically significant), and it was more or less identical among the middle and low status groups (Sogner, Randsborg, and Fure 1984). Nonetheless, the fertility decline started in the higher social groups, and then spread to the lower status groups.

In his study of the socioeconomic fertility differentials in Britain during the fertility decline, which was based on the 1911 census, Szreter (1996) stressed the interplay of geography and class in the decline. Fertility decline was not simply diffused socially and geographically following a certain pattern. Instead, there were pronounced 
regional differences within various social groups. These differences appear to be related to the perceived costs of childrearing. As conditions changed, new attitudes and values spread within these regional social groups through a changed discourse. This shift in the discourse was, however, determined to a large extent by changes in the economic conditions. Overall, Szreter downplayed the importance of socioeconomic differentials in fertility during the transition. But this conclusion has recently been challenged by Barnes and Guinnane (2012), who, using the same data, concluded that social class accounted for a large proportion (about two-thirds) of the fertility variance between couples in the 1911 British census. Woods, on the other hand, stressed that while there certainly were class differences in marital fertility in Britain around the turn of the 20th century, the decline occurred among the different classes at more or less the same time (Woods 2000: 116-121).

More recently, following the publication of Clark's A Farewell to Alms, economic historians have displayed renewed interest in the issue of fertility differentials by social class or wealth level (2007; see also Guinnane 2011). Based on data from wills, Clark showed that the number of surviving children was higher among richer families in preindustrial England, but also that these differences diminished well before the fertility transition (see also Clark and Cummins 2009, Clark and Hamilton 2006). Similar results have been found for France (Cummins 2013) and for England using occupational data from family reconstitutions (Boberg-Fazlic, Sharp, and Weisdorf 2011).

From a theoretical point of view, fertility decline is often viewed within the framework of innovation and adjustment (Carlsson 1966): the first model attributes fertility to new knowledge or attitudes regarding fertility control, while the second model sees the decline as having resulted from an adjustment of behavior to new circumstances and a greater motivation to limit fertility. In an alternative, but equally classic, formulation, Coale (1973, later developed by Lesthaeghe and Vanderhoeft 2001) identified three conditions for fertility decline: namely, that people needed to be "ready, willing and able." These three conditions involve both adjustment and innovation.

According to the innovation perspective, fertility before the decline was not deliberately controlled, but was instead "natural” (Henry 1961). Thus, marital fertility was not determined by the decision to stop having children at a certain parity, but rather by the length of the birth intervals. These intervals were in turn determined to a large extent by the length of time spent breastfeeding and the level of infant and early child mortality. Thus, according to this model, the fertility decline was mainly the result of a form of innovation in which couples started limiting their family size by ceasing to have children after reaching a set target (cf. Cleland and Wilson 1987; Coale and Watkins 1986; Knodel and van de Walle 1979). In the words of Coale (1973), fertility came to 
be "within the calculus of conscious choice," which seems to imply that it was not before the transition. Deliberate birth control emerged through the cultural transmission of new ideas and changing attitudes and norms regarding the appropriateness of fertility control within marriage. The spread of such methods also entailed acquiring knowledge about how to limit fertility. Many scholars believe, however, that this knowledge was present long before the decline, even though it may not have been used for parityspecific control, but rather for spacing births or avoiding childbearing in difficult times (see, e.g., Bengtsson and Dribe 2006; David and Sanderson 1986; Dribe and Scalone 2010; Santow 1995; Szreter 1996; Van Bavel 2004).

It might be generally expected that the higher social groups would be more likely to formulate and adopt these new ideas, as these groups were more open culturally, and appear to have felt an increasing need to distinguish themselves from the lower classes. These kinds of strategies of distinction practiced by members of the middle class have been shown to have been important for other aspects of family life, such as for marriage patterns (see Van de Putte 2007; see also Frykman and Löfgren 1987), and they may have been important for childbearing as well. The middle class and elite groups can also be expected to have been in a better position to acquire new knowledge about methods of birth control, to the extent that this information was not generally available before. In other words, assuming that innovation diffusion was important for the decline in fertility - which, after all, has been the orthodox view among historical demographers for a long time-we would expect to see that high social status was connected to an early decline in fertility (see Cleland 2001).

According to the structural adjustment perspective, fertility decline is a response to changes in the motivations for having children. In the theoretical framework outlined by Easterlin and Crimmins (1985), both the demand and the supply of children are important in explaining the high levels of pre-transitional fertility; as it is assumed that knowledge about birth control was available, and was applied once the decline in fertility began. The supply of children is defined as the number of surviving children a couple would have if they made no conscious efforts to limit the size of the family (Easterlin and Crimmins 1985). Thus, it reflects natural fertility as well as child survival. The high levels of mortality of pre-transitional societies (low supply), together with the strong demand for children, meant that the demand exceeded the supply. Following the mortality decline, the supply of children increased, which contributed to the decline in fertility (Galloway, Lee and Hammel 1998; Reher 1999; Reher and SanzGimeno 2007). However, declining mortality was only part of the explanation, as fertility was reduced to a much greater extent than was needed to offset lower mortality. This implies that the fertility decline entailed a reduced number of surviving children; in other words, a decline in net fertility (see Doepke 2005). 
It therefore appears that the changing demand for children was also an important factor in the fertility decline (see Brown and Guinnane 2002; Crafts 1984; Dribe 2009; Galloway, Hammel and Lee 1994; Mosk 1983; Schultz 1985). The demand for children can be defined as the number of children a couple would want to have if there were no costs associated with fertility control. In practice, the decision about how many children to have is generally based on the family's income and the cost of children in relation to other goods that are directly related to social status, economic conditions, and occupational levels. The motivations for having children changed following industrialization and urbanization, although these processes appear to have affected socioeconomic groups differently. On the one hand, a desire for higher levels of consumption among high status groups would have increased the opportunity costs of childbearing, and may therefore have contributed to a reduced demand for children. On the other hand, children may have been able to help the family by working in the fields or by assisting in supplementary activities from a relatively early age. Thus, the economic benefits of having children might have been greater among the lower and middle class families in rural contexts. This could explain the delay in the fertility decline among these groups.

In addition, as industrialization and urbanization increased the returns to education, the demand for child quality also increased (Becker 1991). This led families to substitute quantity for quality, by having fewer children and investing more in each child. This quantity-quality trade-off has been viewed as an important explanation for the decline in fertility (see, e.g., Dribe 2009; Wahl 1992), as well as for the escape from the Malthusian trap and the emergence of modern economic growth (e.g., Galor 2005; see also Becker et al. 2010; Guinnane 2011).

Empirical studies have also confirmed that smaller family sizes in the demographic transition became increasing connected to socioeconomic upward mobility among children (Bras, Kok, and Mandemakers 2010; Van Bavel 2006, Van Bavel et al. 2011). It may be expected that this shift toward increased investments in child quality would have occurred first among the higher status groups, partly because of the higher returns on education for people in higher status occupations, and partly because of the greater degree of knowledge and information about the new conditions among the members of these socioeconomic groups.

After the transition, we expect to see that economic factors played an even bigger role in determining fertility, as deliberate fertility control was now widely accepted. Thus, potential controllers should have encountered much less resistance in the form of negative attitudes and prejudice. Nonetheless, especially in economic research, scholars have strongly emphasized that the spread of the contraceptive pill made fertility control much more efficient, and thus had far-reaching effects on women's education and career choices (Bailey 2010; Goldin and Katz 2002). It may therefore be expected that 
highly educated women who were married to professional men would have had lower fertility, especially in the 1970 census.

In addition to this possible effect of the contraceptive revolution of the 1960s, it may be assumed that fertility was connected to social class mainly through the families' income levels and their aspirations for their children (child quality). In the economic fertility models, having a higher income, and thus belonging to a higher social class, provides economic opportunities for larger families (e.g., more spacious housing, domestic servants, higher levels of consumption). At the same time, the opportunity costs of parental time devoted to children would be expected to be higher in the upper classes, which should lead to lower fertility. Finally, the trade-off between the quantity and the quality of children may be expected to be stronger among middle-class families because they have higher aspirations for their children, which entails long periods spent in education and more expensive lifestyles (e.g., clothing and leisure activities). We may therefore assume that the income effect would be greater than all of the other effects and would lead to large families only among the very wealthy; whereas among the aspiring middle class, the quantity-quality trade-off would be greater than the income effect, leading to low fertility even in contexts in which women are homemakers. In the countryside, on the other hand, this trade-off would be much less pressing: the comparatively spacious housing, the low educational levels, the traditional attitudes, and the low opportunity costs given the close proximity of work and home, would lead rural families to have relatively high fertility levels.

Based on the preceding discussion, we expect to see a positive association between fertility and socioeconomic status before the fertility transition, at least in terms of total fertility (for marital fertility this is less clear). More relevant for this study is, however, the expectation that we will observe that the decline occurred earlier among the higher status groups, leading to lower fertility levels among these groups early in the transition. It appears likely that this pattern prevailed after the transition, except perhaps among the upper classes. Moreover, we expect to see substantial geographical differences in the extent of the fertility decline, both between the different regions and between the urban and the rural areas. Because the patterns of socioeconomic stratification also differ regionally, we anticipate that the socioeconomic differentials will be smaller after we take the spatial patterns into account.

\section{Data}

We use micro-level data from five different Swedish censuses (1880, 1890, 1900, 1960, and 1970). Data for the first three censuses were digitized by the Swedish National Archives, and are published by the North Atlantic Population Project (NAPP, see 
Ruggles et al. 2011; Sobek et al. 2011), which has adopted the same format as the Integrated Public Use Microdata Series (IPUMS). Here we have used the original data coded by the Swedish National Archives within the project SweCens (funded by the Swedish Research Council). All of the registered individuals are grouped by household. Thus, each individual record reports the household index number and the person index within the household. The age, marital status, and sex of each person are also registered. The migration status indicates whether a person was born in the same county of residence or in another county or country. A specific variable also reports each person's relationship to the household head. In addition, there are family pointer variables indicating the personal number within the household of the mother, the father, and the spouse, making it possible to link each woman to her own children and husband. In total, the 1880 census counted about 4.6 million persons in 1.2 million households from about 2,500 parishes, while the corresponding figures in the 1890 and 1900 censuses are 4.8/1.3 and 5.2/1.4 million, respectively.

The data for the post-transition period come from the digitized censuses (Folk och bostadsräkningen) of 1960 and 1970, which were carried out by Statistics Sweden. The structure of the data is similar to that of the historical censuses. In addition to personal identifiers, there are household links and position, which makes it possible to identify children living in the parental home. We have also linked the censuses to the multigeneration register (Flergenerationsregistret) maintained by Statistics Sweden, which contains all of the individuals who have resided in Sweden since 1960, and links them (based on personal numbers) to their biological and adopted children. In total, the 1960 census counted 6.9 million individuals ( 2.3 million households), and the 1970 census recorded 7.9 million individuals in 2.9 million households.

From these five censuses, we created a sample of married women aged 15-54. This was done to ensure that all of the children aged 0-4 born to women aged 15-49 were included. Only married women with their spouses present were included in the analysis. The descriptive statistics of these samples are presented in Table 1 . This process left us with a sample consisting of around 600,000 women in each of the first three censuses and of 1.3 million women in the two latter censuses. 
Table 1: Descriptive statistics of cross sections (\%)

\begin{tabular}{|c|c|c|c|c|c|}
\hline & 1880 & 1890 & 1900 & 1960 & 1970 \\
\hline \multicolumn{6}{|l|}{ SES (EGP) } \\
\hline Higher professionals, managers (I) & 2.7 & 2.7 & 2.9 & 6.1 & 6.7 \\
\hline Lower professionals, managers (II) & 2.2 & 2.4 & 2.8 & 17.7 & 23.1 \\
\hline Routine non-manual workers (III) & 0.6 & 1.0 & 1.5 & 7.4 & 7.0 \\
\hline Petty bourgeoisie (IVa+IVb) & 2.6 & 3.9 & 4.7 & 7.4 & 6.1 \\
\hline Skilled workers $(\mathrm{V}+\mathrm{VI})$ & 14.8 & 17.6 & 20.5 & 26.4 & 26.8 \\
\hline Non-skilled workers (VIIa) & 22.1 & 19.0 & 20.7 & 16.9 & 14.6 \\
\hline Agricultural laborers (VIIb) & 6.0 & 9.6 & 8.4 & 2.8 & 1.6 \\
\hline Farmers (IVc) & 42.0 & 38.3 & 33.2 & 9.8 & 5.4 \\
\hline No class & 4.6 & 3.6 & 3.5 & 3.3 & 4.0 \\
\hline No occupation & 2.3 & 1.9 & 1.6 & 2.3 & 4.8 \\
\hline \multicolumn{6}{|l|}{ Age of woman } \\
\hline 15-19 & 0.4 & 0.4 & 0.4 & 0.5 & 0.3 \\
\hline $20-24$ & 6.0 & 5.4 & 6.5 & 6.8 & 8.6 \\
\hline $25-29$ & 13.5 & 14.1 & 13.6 & 12.3 & 16.2 \\
\hline 30-34 & 16.7 & 17.9 & 15.8 & 14.9 & 14.6 \\
\hline 35-39 & 17.7 & 17.3 & 18.2 & 17.1 & 13.9 \\
\hline 40-44 & 16.2 & 16.2 & 17.4 & 17.0 & 14.8 \\
\hline $45-49$ & 15.7 & 15.4 & 15.0 & 16.3 & 16.2 \\
\hline 50-54 & 13.7 & 13.2 & 13.0 & 15.1 & 15.5 \\
\hline \multicolumn{6}{|l|}{ Age difference between spouses } \\
\hline Wife older & 27.9 & 26.9 & 26.0 & 15.8 & 13.8 \\
\hline Husband 0-2 older & 21.3 & 22.0 & 22.7 & 28.5 & 32.5 \\
\hline Husband 3-6 older & 25.1 & 25.6 & 26.3 & 34.3 & 35.3 \\
\hline Husband $>6$ older & 25.6 & 25.6 & 24.9 & 21.4 & 18.5 \\
\hline \multicolumn{6}{|l|}{ Children $>4$ years at home } \\
\hline No & 30.9 & 29.9 & 29.6 & 32.6 & 34.3 \\
\hline Yes & 69.1 & 70.1 & 70.4 & 67.4 & 65.7 \\
\hline \multicolumn{6}{|l|}{ Woman employed } \\
\hline No & 99.6 & 99.5 & 99.4 & 73.8 & 46.0 \\
\hline Yes & 0.4 & 0.5 & 0.6 & 26.2 & 54.0 \\
\hline $\mathrm{N}$ & 580,849 & 586,918 & 619,096 & $1,262,706$ & $1,297,635$ \\
\hline
\end{tabular}

Sources: 1880-1900: Micro censuses (SweCens), the Swedish National Archives; 1960-1970: Census data and the Multigeneration register, Statistics Sweden. 
Our decision to use the husband's occupation as the core information for identifying a family's social class is based on a long tradition in social stratification research (see, e.g., Van Leeuwen and Maas 2010). In the historical census data, individual occupations were coded according to the Historical International Standard Classification of Occupations (HISCO; Van Leeuwen, Maas, and Miles 2002). In the censuses of 1960 and 1970, the occupational data were coded according to a standard developed by Statistics Sweden (SSYK). Historical studies (19th century) of social stratification and mobility often used the HISCLASS (Van Leeuwen and Maas 2011) or the SOCPO (Van de Putte and Miles 2005) to categorize occupations according to social groups or classes. In contemporary research, a wider range of methods have been used to indicate class or socioeconomic status, all of them linked to different ideas and theories on class and stratification itself (see, e.g., Thålin 2007). In the current study, we have chosen use a scheme developed by Erikson, Golthorpe, and Portocarero (1979); hereafter called the EGP. ${ }^{3}$ Like the HISCLASS, the EGP is based on skill level (manual, non-manual, etc.), employment relations (employee, self-employed, employer), and sector (rural, non-rural) (see Erikson and Goldthorpe 1992:35-47). Here we use an eight-class version of this scheme: higher professionals and managers (I), lower professionals and managers (II), non-manual workers (III), petty bourgeoisie $(\mathrm{IVa}+\mathrm{b})$, farmers (IVc), skilled workers (V+VI), non-skilled workers (VIIa), and agricultural laborers (VIIb).

Table 1 gives distributions of the samples across the different classes. Farmers (including smallholders) appear to have dominated the social structure in 1880, which is indicative of the highly rural character of Sweden at that time. During the first half of the 20th century, a huge transformation of the social structure took place. This is clearly visible in the table: around 1900 , about $35 \%$ of the population belonged to the farmer group, compared to only 5\%-10\% in 1960 and 1970 . A similar decline can be seen for farm workers. Meanwhile, the shares of skilled workers and service class workers increased greatly.

In the analysis, we also controlled for age, the age difference between the spouses, the presence in the family of children over age four, and the employment status of the wife. The latter factor was difficult to measure because of the problems associated with farming. Counting all of the wives in the farming sector as employed would have produced much higher estimates than the ones presented here, which included only the occupations noted in the sources (i.e., the husband's but not the wife's occupation). For

\footnotetext{
${ }^{3}$ To classify from the HISCO to the EGP, we used a transcode table developed, and kindly shared, by Ineke Maas at Utrecht University (Maas 2000). To classify the SSYK in 1960 and 1970 into the EGP, we used the transcode table developed by Erik Bihagen at SOFI, Stockholm University (http://www2.sofi.su.se/ ebi/). We are grateful to Erik for his valuable advice.
} 
example, the data indicated that only around $0.5 \%$ of all married women in the age group 15-54 were gainfully employed outside of a farm around 1900 (see Table 1). According to the census of 1920, the corresponding figure was $4 \%$ (Silenstam 1970:56). While it is likely that a large number of married women did various kinds of work to supplement the family income, this work generally would not have been recorded in the sources. In later census years the registration of female labor force participation appears to have been much more accurate, as the figure had risen to $26 \%$ in 1960 and to $54 \%$ in 1970.

\section{Methods}

Count variables with relatively low means, such as the number of own children per woman, frequently exhibit distributions that approximate Poisson distributions (Long 1997). Therefore, a Poisson regression was adopted to estimate the association between social class and net fertility. More formally, the Poisson regression model assumes that the $n$ observations $y_{i}$ are drawn from independent Poisson variables $Y_{i}$ with mean $\mu_{i}$. On the basis of the observed characteristics, $\mu$ can be estimated as:

$$
\mu_{i j}=\exp \left(x_{i j} \beta+v_{j}\right)
$$

where $\mu_{\mathrm{ij}}$ is the number of children for woman $\mathrm{i}$ living in parish $\mathrm{j}, \mathrm{x}_{\mathrm{ij}}$ is a vector of $\mathrm{k}$ characteristics of the woman $\mathrm{ij}$, the vector $\beta$ contains the $\mathrm{k}$ parameters of the individual covariates, and $v_{\mathrm{j}}$ denotes parish-specific fixed effects. This model controls for parishlevel unobserved heterogeneity. As a comparison, we also estimated negative binomial models, which were robust against overdispersion in the data (see Cameron and Trivedi 2009). They yielded practically identical results in terms of both the estimates and the p-values. In the tables below we only report the Poisson estimates.

The aim was to control for a number of possible explanatory variables and spatial heterogeneity in estimating the association. The main covariate was social class, which was derived from the occupation of the husband. In the first step of the analysis, we estimated separate models for each census. We will present the model results reporting the incidence rate ratio (IRR), which expresses the relative change in the number of children for a unit change in the explanatory variable, holding all the other variables constant. 


\section{Net fertility by socioeconomic status}

For Sweden in this period, we have data that allow us to derive age-specific fertility (both total and by marital status) at the national and the county levels. However, these kinds of detailed demographic data are not available by socioeconomic status. Nationwide data on occupation at the individual level can be found only in the censuses. Census data do not allow for the computation of standard fertility rates (ASMFR, TMFR, etc.) because they do not contain records of births, but only of the children present in the family. We have therefore chosen to use an indirect measure of fertility called the child-woman ratio (CWR). The CWR has traditionally been defined as the number of children aged 0-4 per 1,000 women aged 15-49 (Shryock and Siegel 1980). It is easy to see that the children under age five may have been born during the five-year period before the census date, when the women were up to five years younger. In a previous paper using the 1900 census, we compared the CWR to other standard fertility measures, as well as to another indirect method (the own-children method) (See Scalone and Dribe 2012). We demonstrated that the unadjusted CWR reflected rather well the socioeconomic differentials in terms of gross, or total, marital fertility. In the appendix, we made the same comparison to mortality-adjusted CWR for two other regions in Sweden. This further supports the conclusion that the socioeconomic differences in marital net fertility closely resembles the socioeconomic pattern in marital fertility (see the appendix). In the 1960s, infant mortality and child mortality were so low that it is unlikely these rates would have greatly affected these kinds of estimates, despite the fact that the relative mortality differences were much larger than they were before (see Bengtsson and Dribe 2011).

For the censuses of 1960 and 1970, we compared the number of children aged 0-4 in the census to the number of children actually born based on the multigeneration register. In 1960, the CWR exactly matched the number of biological and adopted children according to the multigeneration register; while in 1970, the number of children was slightly higher according to the multigeneration register. This discrepancy is probably attributable to the greater frequency of divorce, after which children no longer live with both of their biological parents. Yet the socioeconomic differences were shown to be highly similar regardless of the measure used. To ensure comparability with the historical censuses, we used the number of children recorded in the censuses.

The CWR can also be viewed as a measure of net fertility (i.e., fertility adjusted for mortality in the first five years of life). In many ways, this is a more informative measure of fertility, as we expect that the families cared more about the number of surviving children than the number of births. While the fertility transition came about in part as a response to lower mortality (e.g., Galloway, Lee, and Hammel 1998; Reher 
1999; Reher and Sanz-Gimeno 2007; see also Dyson 2010), it is obvious that the decline in net fertility was much more important in the long run (see, e.g., Doepke 2005; Haines 1998).

Table 2 shows the CWR (aged 0-4) by social class in the five censuses. We can immediately see that net fertility was lower in 1960/70, and was clearly consistent with the course of the fertility transition. The net fertility was also about 5\% lower in 1900 than it was in 1890, which shows that this was a period of decline. Meanwhile, it actually increased somewhat between 1880 and 1890. This increase might be attributable to a more rapid decline in mortality than in fertility in this period, which undoubtedly was a period of decline in aggregate total fertility (see Dribe 2009). Between 1960 and 1970, net fertility increased slightly, reflecting the second baby boom in Sweden in the late 1960s (see, e.g., Stanfors 2003).

Table 2: $\quad$ Mean number of children (aged 0-4) per woman by SES

\begin{tabular}{lrrrrr}
\hline & 1880 & 1890 & 1900 & 1960 & 1970 \\
\hline Higher professionals, managers (I) & 0.78 & 0.72 & 0.68 & 0.36 & 0.38 \\
Lower professionals, managers (II) & 0.91 & 0.85 & 0.72 & 0.39 & 0.39 \\
Routine non-manual workers (III) & 0.90 & 0.83 & 0.69 & 0.34 & 0.30 \\
Petty bourgeoisie (IVa+IVb) & 0.91 & 0.83 & 0.73 & 0.27 & 0.29 \\
Skilled workers (V+VI) & 0.96 & 0.98 & 0.92 & 0.37 & 0.40 \\
Non-skilled workers (VIIa) & 0.88 & 0.93 & 0.89 & 0.34 & 0.37 \\
Agricultural laborers (VIIb) & 0.95 & 0.96 & 0.95 & 0.43 & 0.40 \\
Farmers (IVc) & 0.85 & 0.85 & 0.84 & 0.33 & 0.28 \\
No class & 0.83 & 0.82 & 0.84 & 0.37 & 0.33 \\
No occupation & 0.58 & 0.56 & 0.54 & 0.25 & 0.31 \\
& & & & & \\
Total & 0.87 & 0.89 & 0.85 & 0.35 & 0.37 \\
\hline
\end{tabular}

Note: Based on number of children aged 0-4 listed in the census. Sources: See Table 1.

When we look at class differences, we can see that they did not decline over time if measured in relative terms. The difference between highest and lowest was about $23 \%$ in $1880,36 \%$ in 1890 , and $40 \%$ in 1900 . In all three cases, the highest status group 
(I) had the lowest fertility, while the skilled workers (V+VI) and the agricultural laborers (VIIb) had the highest fertility. In 1960, the relative difference between the agricultural laborers with the highest fertility and the petty bourgeoisie (IVa+b) with the lowest fertility was almost $60 \%$. In 1970 , the maximum difference was $43 \%$, with the agricultural laborers and the skilled workers having the highest fertility and the farmers having the lowest fertility. Thus, while the magnitude of the relative class differences in fertility did not change that much, the pattern of higher status groups having low fertility and lower status groups having high fertility was not as clear. Moreover, we found no indication of higher fertility in the elite groups before the transition, as has sometimes been observed. Before reading too much into this, however, it is important to note that we have not controlled for the differences between these groups in terms of age or other variables.

\section{Regression results}

Table 3, panel A, displays rate ratios from Poisson regressions (they can be interpreted as relative net fertility rates) in a basic model without any covariates. The table gives basically the same picture as Table 2, indicating similar magnitudes-but different patterns - in the class differences before, during, and after the transition. In 1880, the skilled workers and the agricultural laborers had higher fertility than most of the other groups, while the elite group had the lowest. The upper-middle and the middle classes did not, however, have distinctly lower fertility. This pattern was quite similar in 1890, but the difference between the working classes and the middle classes was larger than in 1880. The elite still had the lowest fertility of all of the groups. In 1900, the fertility of the upper and the middle classes had converged, and there were now two quite distinct groups: the working classes and the farmers on one hand, and the middle and the upper classes on the other. In 1960/70, the petty bourgeoisie had the lowest level of net fertility, while the higher and the lower classes had higher fertility levels. 
Table 3: Rate ratios from Poisson regression of number of children aged 0-4. Married women aged 15-54

A. Basic model

\begin{tabular}{|c|c|c|c|c|c|c|c|c|c|c|}
\hline & \multicolumn{2}{|c|}{1880} & \multicolumn{2}{|c|}{1890} & \multicolumn{2}{|c|}{1900} & \multicolumn{2}{|c|}{1960} & \multicolumn{2}{|c|}{1970} \\
\hline & IRR & $P>|t|$ & IRR & $P>|t|$ & IRR & $P>|t|$ & IRR & $P>|t|$ & IRR & $P>|t|$ \\
\hline \multicolumn{11}{|l|}{ SES (EGP) } \\
\hline Higher & & & & & & & & & & \\
\hline $\begin{array}{l}\text { professionals, } \\
\text { managers (I) }\end{array}$ & 1 & ref & 1 & ref & 1 & ref & 1 & ref & 1 & ref \\
\hline Lower & & & & & & & & & & \\
\hline $\begin{array}{l}\text { professionals, } \\
\text { managers (II) }\end{array}$ & 1.17 & 0.000 & 1.18 & 0.000 & 1.06 & 0.000 & 1.10 & 0.000 & 1.03 & 0.000 \\
\hline $\begin{array}{l}\text { Routine non- } \\
\text { manual workers (III) }\end{array}$ & 1.16 & 0.000 & 1.16 & 0.000 & 1.02 & 0.313 & 0.96 & 0.000 & 0.80 & 0.000 \\
\hline $\begin{array}{l}\text { Petty bourgeoisie } \\
(\mathrm{IVa}+\mathrm{IVb})\end{array}$ & 1.18 & 0.000 & 1.16 & 0.000 & 1.08 & 0.000 & 0.77 & 0.000 & 0.75 & 0.000 \\
\hline $\begin{array}{l}\text { Skilled workers } \\
(\mathrm{V}+\mathrm{VI})\end{array}$ & 1.24 & 0.000 & 1.37 & 0.000 & 1.35 & 0.000 & 1.04 & 0.000 & 1.06 & 0.000 \\
\hline $\begin{array}{l}\text { Non-skilled workers } \\
\text { (VIla) }\end{array}$ & 1.13 & 0.000 & 1.30 & 0.000 & 1.31 & 0.000 & 0.97 & 0.000 & 0.98 & 0.000 \\
\hline $\begin{array}{l}\text { Agricultural } \\
\text { laborers (VIIb) }\end{array}$ & 1.23 & 0.000 & 1.34 & 0.000 & 1.40 & 0.000 & 1.20 & 0.000 & 1.05 & 0.000 \\
\hline Farmers (IVc) & 1.10 & 0.000 & 1.18 & 0.000 & 1.23 & 0.000 & 0.94 & 0.000 & 0.74 & 0.000 \\
\hline No class & 1.07 & 0.000 & 1.14 & 0.000 & 1.23 & 0.000 & 1.04 & 0.000 & 0.87 & 0.000 \\
\hline No occupation & 0.75 & 0.000 & 0.78 & 0.000 & 0.79 & 0.000 & 0.70 & 0.000 & 0.82 & 0.000 \\
\hline Log likelihood & $-709,660$ & & $-725,803$ & & $-757,607$ & & $-969,760$ & & $-1,013,000$ & \\
\hline Overall p & 0.000 & & 0.000 & & 0.000 & & 0.000 & & 0.000 & \\
\hline
\end{tabular}

Note: Basic model include no control variables.

Sources: See Table 1. 
Dribe \& Scalone: Social class and net fertility before, during, and after the demographic transition

B. Full model

\begin{tabular}{|c|c|c|c|c|c|c|c|c|c|c|}
\hline & \multicolumn{2}{|c|}{1880} & \multicolumn{2}{|c|}{1890} & \multicolumn{2}{|c|}{1900} & \multicolumn{2}{|c|}{1960} & \multicolumn{2}{|c|}{1970} \\
\hline & IRR & $P>|t|$ & IRR & $P>|t|$ & IRR & $P>|t|$ & IRR & $P>|t|$ & IRR & $P>|t|$ \\
\hline \multicolumn{11}{|l|}{ SES (EGP) } \\
\hline $\begin{array}{l}\text { Higher } \\
\text { professionals, } \\
\text { managers (I) }\end{array}$ & 1 & Ref & 1 & ref & 1 & Ref & 1 & ref & 1 & ref \\
\hline $\begin{array}{l}\text { Lower } \\
\text { professionals, } \\
\text { managers (II) }\end{array}$ & 1.09 & 0.000 & 1.05 & 0.000 & 0.97 & 0.044 & 0.93 & 0.000 & 0.92 & 0.000 \\
\hline $\begin{array}{l}\text { Routine non- } \\
\text { manual workers } \\
\text { (III) }\end{array}$ & 1.04 & 0.082 & 0.99 & 0.438 & 0.91 & 0.000 & 0.88 & 0.000 & 0.89 & 0.000 \\
\hline $\begin{array}{l}\text { Petty bourgeoisie } \\
(I V a+I V b)\end{array}$ & 1.08 & 0.000 & 1.05 & 0.000 & 1.01 & 0.292 & 0.92 & 0.000 & 0.89 & 0.000 \\
\hline $\begin{array}{l}\text { Skilled workers } \\
(\mathrm{V}+\mathrm{VI})\end{array}$ & 1.12 & 0.000 & 1.16 & 0.000 & 1.14 & 0.000 & 0.90 & 0.000 & 0.92 & 0.000 \\
\hline $\begin{array}{l}\text { Non-skilled } \\
\text { workers (VIIa) }\end{array}$ & 1.06 & 0.000 & 1.11 & 0.000 & 1.10 & 0.000 & 0.93 & 0.000 & 0.94 & 0.000 \\
\hline $\begin{array}{l}\text { Agricultural } \\
\text { laborers (VIIb) }\end{array}$ & 1.06 & 0.000 & 1.12 & 0.000 & 1.13 & 0.000 & 0.97 & 0.008 & 0.94 & 0.000 \\
\hline Farmers (IVc) & 1.06 & 0.000 & 1.11 & 0.000 & 1.12 & 0.000 & 1.04 & 0.000 & 1.10 & 0.000 \\
\hline No class & 0.95 & 0.000 & 0.96 & 0.001 & 0.98 & 0.141 & 0.92 & 0.000 & 0.90 & 0.000 \\
\hline No occupation & 0.98 & 0.133 & 0.98 & 0.138 & 0.98 & 0.137 & 0.86 & 0.000 & 0.78 & 0.000 \\
\hline Log likelihood & $-589,901$ & & $-603,676$ & & $-632,411$ & & $-716,580$ & & $-720,561$ & \\
\hline Overall p & 0.000 & & 0.000 & & 0.000 & & 0.000 & & 0.000 & \\
\hline
\end{tabular}

Note: Full models control for age of woman, age difference between spouses, children over age four, female employment, and parish-level fixed effects.

Sources: See Table 1.

Panel B shows the estimates of a full model, including controls for age, the age difference between the spouses, the presence of children over four, female employment, and parish-level fixed effects. This model appears to have been rather efficient in controlling for unobserved geographical heterogeneity, as the identification was based completely on intra-parish differences. The pattern was also rather different from that of 
the basic model. Overall, the magnitudes in the differences were lower, which shows that a considerable portion of the class differences may be explained by factors other than class in itself (cf. Garrett et al. 2001; Scalone and Dribe 2012). We still found the lowest fertility in the highest classes during the transition. In fact, the pattern generally showed two different groups; a low-fertility group consisting of the upper and the middle classes (I, II, III, IVa+IVb), and a high-fertility group consisting of the rest; i.e., of the working classes and the farmers. The magnitudes of the differences were about $10 \%$ (the maximum difference between the farmers and the routine non-manual workers was about 30\%). The main change between 1890 and 1900 was a decline in the net fertility levels of the upper-middle and the middle classes (II, III, IVa+b), implying a convergence to the level of the upper class.

To delve more deeply into the SES differences prior to and early in the transition, we estimated a set of full models whereby the SES was interacted with a variable indicating whether the county had or had not entered the transition (see Table 4). All of the counties in 1880, 1890, and 1900 with a Coale-Trussel "m" greater than 0.2 (which is commonly taken to indicate the presence of parity-specific birth control) were considered as having been "in transition" (see Coale and Trussel 1974, 1978; data from Dribe 2009). Overall, the pattern was rather similar in the transition and the nontransition counties, but the class differences were larger in the transition counties. Thus, it appears that the socioeconomic differentials widened in the fertility transition in Sweden as well (cf. Haines 1992). It is also interesting to note that the elite group (I) stands out as having had low fertility even in the pre-transition counties in 1880. In Stockholm city and Gotland ("in transition") the differences were larger. It should be noted that the island of Gotland was always known for its low fertility (e.g., Gaunt 1973; Wohlin 1915), and that Stockholm city did not have farmers and agricultural laborers; thus, the low fertility in these groups reflected geographic differences more than class differences.

Outside of the agricultural classes, the elite group clearly had the lowest fertility level, and the other groups had similar levels among themselves. The large difference found between the higher professionals/managers and the lower professionals/managers is interesting, as it shows that the elite group led the transition, despite the fact that their fertility had been somewhat lower even before the transition started. In 1890 and 1900, it is interesting to note that the upper classes had lower fertility even in the "no transition" counties, but that the differentials were always bigger in the counties that had started the transition (which in these years included more counties than just Stockholm city and Gotland). In other words, the results make it quite clear that there was no "survival of the richest" just before the fertility transition (i.e., in which the upper classes had higher fertility), but that the upper classes acted as forerunners once the decline was under way. It is impossible to tell from our data whether fertility among 
the upper classes had been higher long before the transition; and then, as in England, underwent a pre-transition decline which led to a convergence with the levels of the other groups (cf. Boberg-Fazlic, Sharp, and Weisdorf 2011; Clark and Hamilton 2006). The micro-level results for Scania in southern Sweden indicate that this might well have been the case in Sweden as well (Bengtsson and Dribe 2014)

Table 4: Net effects of SES on number of children per woman by transition phase in county

A. 1880

\begin{tabular}{lcrrr}
\hline & In transition & No transition \\
\hline & IRR & $\mathrm{p}$ & $\mathrm{IRR}$ & $\mathrm{p}$ \\
Higher professionals, managers (I) & 1.00 & 0.966 & 1 & ref \\
Lower professionals, managers (II) & 1.15 & 0.308 & 1.09 & 0.00 \\
Routine non-manual workers (III) & 1.12 & 0.088 & 1.03 & 0.17 \\
Petty bourgeoisie (IVa+IVb) & 1.15 & 0.082 & 1.07 & 0.00 \\
Skilled workers (V+VI) & 1.21 & 0.033 & 1.11 & 0.00 \\
Non-skilled workers (VIIa) & 1.07 & 0.726 & 1.05 & 0.00 \\
Agricultural laborers (VIIb) & 0.96 & 0.056 & 1.06 & 0.00 \\
Farmers (IVc) & 1.05 & 0.847 & 1.06 & 0.00 \\
No class & 0.83 & 0.041 & 0.94 & 0.00 \\
No occupation & 0.00 & 0.000 & 0.99 & 0.33 \\
\hline
\end{tabular}

B. 1890

\begin{tabular}{lcrrr}
\hline & In transition & \multicolumn{2}{c}{ No transition } \\
\hline & IRR & $\mathrm{p}$ & IRR & $\mathrm{p}$ \\
Higher professionals, managers (I) & 1.07 & 0.090 & 1 & ref \\
Lower professionals, managers (II) & 1.13 & 0.077 & 1.04 & 0.00 \\
Routine non-manual workers (III) & 1.05 & 0.068 & 0.98 & 0.38 \\
Petty bourgeoisie (IVa+IVb) & 1.17 & 0.000 & 1.04 & 0.00 \\
Skilled workers (V+VI) & 1.30 & 0.000 & 1.14 & 0.00 \\
Non-skilled workers (VIIa) & 1.28 & 0.000 & 1.10 & 0.00 \\
Agricultural laborers (VIIb) & 1.17 & 0.059 & 1.09 & 0.00 \\
Farmers (IVc) & 1.16 & 0.222 & 1.10 & 0.00 \\
No class & 0.97 & 0.720 & 0.95 & 0.00 \\
No occupation & 0.00 & 0.000 & 0.98 & 0.21 \\
\hline
\end{tabular}


Table 4: (Continued)

C. 1900

\begin{tabular}{lcccr}
\hline & In transition & \multicolumn{3}{c}{ No transition } \\
\hline Higher professionals, managers (I) & IRR & $\mathrm{p}$ & IRR & $\mathrm{p}$ \\
Lower professionals, managers (II) & 1.04 & 0.116 & 1.00 & ref \\
Routine non-manual workers (III) & 1.02 & 0.058 & 0.96 & 0.01 \\
Petty bourgeoisie (IVa+IVb) & 0.91 & 0.204 & 0.88 & 0.00 \\
Skilled workers (V+VI) & 1.03 & 0.144 & 1.00 & 0.95 \\
Non-skilled workers (VIIa) & 1.17 & 0.035 & 1.12 & 0.00 \\
Agricultural laborers (VIIb) & 1.18 & 0.000 & 1.08 & 0.00 \\
Farmers (IVc) & 1.04 & 0.042 & 1.08 & 0.00 \\
No class & 1.18 & 0.153 & 1.14 & 0.00 \\
No occupation & 0.98 & 0.697 & 0.97 & 0.04 \\
& 0.00 & 0.000 & 0.97 & 0.21 \\
\hline
\end{tabular}

Note: Based on interactions in the full model. "No transition" is the reference category, and p-values refer to the base effects of SES

in the regression. P-values for "In transition" refer to interaction effects. Counties in transition are those with Coale-Trussel "m">0.2 (see Dribe 2009: 76).

Sources: See Table 1.

In the 1960s, these patterns were quite different (see Table 3). According to the 1970 estimates, the rate ratios span a wider range than in 1900, amounting to a $25 \%$ higher net fertility among the farmers than among the petty bourgeoisie. Thus, the farmers stand out as having been the group with the highest fertility in both 1960 and 1970. The petty bourgeoisie (IVa+b) and the non-manual workers (III) had the lowest fertility levels, while the upper class (I) had the second-highest marital fertility level after the farmers. If we exclude the farmers from the picture, we can see a clear Ushaped pattern in 1960; this pattern was a little weaker in 1970, but was qualitatively the same. The reasons for the higher fertility levels in these different classes could, of course, be totally different: among the upper classes, the high incomes of the male breadwinner families may have meant that there were few restrictions on fertility; whereas among the working classes, the most efficient contraceptives might have been adopted later, or positive attitudes toward larger families may have lingered. Farmers also faced fewer constraints on fertility because they worked at or close to home, and they also had more space in their houses. To some extent a greater demand for children to work on the farm may also have played a role, although the labor provided by children would have been much less of a factor in 1970 than it was in the past. The aspiring middle classes (especially III, IVa+b), on the other hand, are the groups for which we expected to find the strongest trade-off between the number of children and 
investments in children. Middle-class parents often had educational ambitions for their children at a time when the costs of having children in education were substantial; not primarily because of school fees, but because schoolchildren were not working and contributing to the upkeep of the household. Thus, the low fertility in this group makes sense from an economic point of view.

These results were all based on separate cross-sections. In order to corroborate the results in a more dynamic perspective, we also linked the censuses and studied how an individual's class in one census affected the number of children aged 0-9 he or she had in the subsequent census. We linked the censuses of 1880 and 1890 as well as the censuses of 1890 and 1900 . These links were based on a probabilistic linking procedure using Jaro-Winkler scores for first name and last name similarities (Christen 2008). ${ }^{4}$ The results showed that $52 \%$ of the married women aged 15-44 in 1880 could be linked to the 1890 census with the same spouse present. The corresponding linkage ratio for $1890 / 1900$ was $58 \%$. This gave us about 213,000 married women in the $1880 / 90$ sample and 242,000 in the 1890/1900 sample. Linking the censuses of 1960 and 1970 was more straightforward, as these censuses included unique individual identifiers based on the personal numbers in the registers. Using this simple procedure, we linked $87.7 \%$ of the married women aged 15-44 in 1960 to the 1970 census with the same spouse present. The results obtained were very similar to the cross-sectional results. This is reassuring, as we can see that the patterns were the same when we followed the same women over a 10-year period as they were when we looked at a cross-section (results not shown). The upper and the middle classes in 1890 had fewer children in 1900 than the other groups, and the farmers in 1960 had more children under age 10 in 1970 than the other groups.

\section{Conclusion}

Class differences in fertility have not received as much scholarly attention as class differences in mortality, a topic for which there is a vast body of literature on the periods before, during, and after the demographic transition. Moreover, in fertility research most of the attention has been devoted to the other determinants, such as education, religion, labor force participation, and public policy. Based on the research available, the conventional wisdom among scholars seems to be that the class differences in fertility reversed during the demographic transition: i.e., the upper classes had higher fertility prior to the transition, and lower fertility after the transition.

\footnotetext{
${ }^{4}$ We are grateful to Björn Eriksson at the Department of Economic History, Lund University, for his valuable help and advice in doing the linkage.
} 
Our results for Sweden only partly confirm this view. There was no indication that elite groups had higher fertility than the other groups immediately before the transition. Instead, most of the evidence suggests that the class differences in fertility were smaller before the transition than they were early in the transition or after the transition. The class differences were about as large in the early phases of the transition as they were in the 1960s. The gap between the high and the low fertility classes was around $40 \%$ or more. Before the transition, the gap was only about $20 \%$.

In the early phases of the decline, the upper and the middle classes had much lower net fertility than the lower skilled workers. However, there is no clear gradient going from highest to lowest socioeconomic status. Instead, it appears that the upper and the middle classes had low fertility, while the rest of the classes had a relatively uniform level of high fertility. In the 1960s, the middle class had the lowest fertility level; while the farmers, the rural laborers, and the elite had the highest levels.

At the turn of 20th century, the upper classes clearly led the other groups in the fertility decline. The elite groups had the lowest fertility levels in the 1880 and 1890 censuses, and the middle classes quickly converged to these low levels in 1900. Meanwhile, the other social groups had almost the same fertility levels as they did 10 years before. It thus appears that, despite the socioeconomic changes that were occurring at the onset of the fertility decline, a kind of barrier continued to isolate the leaders in this trend, which may have prevented the diffusion of new ideas regarding contraception to all the social groups. On the other hand, if we look at the posttransition period, we can see that reproductive behavior became more diversified, changing in response to the constraints and the needs of each social class. At least to some extent, this pattern was different from the pattern found in Britain. According to Woods (2000), the fertility decline there occurred almost simultaneously in all of the classes, even though there were considerable class differences in marital fertility levels before the decline which persisted in the transition. This led Woods to conclude that there was no social diffusion in the fertility transition (Woods 2000:121).

Overall, our findings provide no clear support for the assumption that there was a reversal of class differences in marital fertility in the demographic transition, whereby the upper classes had high fertility and lower classes had low fertility prior to the transition, and the situation reversed after the transition. It is clear that class mattered, but the pattern has no simple gradient. Instead, the specific conditions of the different classes in terms of their income, education, attitudes, and aspirations for their children created different incentives which then determined the outcome. Geography was also important. As we showed in a previous analysis of the 1900 census (Scalone and Dribe 2012), spatial heterogeneity explained up to half of the class differences on the national level. Thus, it is important to look at class differences in a spatial context. 
Nonetheless, even after we included powerful controls for unobserved spatial heterogeneity, we found clear class differences in net fertility, and the basic pattern was more or less unchanged. The finding that the upper classes had low fertility in the early phases of the transition is consistent with explanations which focused both on the adjustment of fertility to the new socioeconomic circumstances, and on the diffusion of new attitudes toward birth control and the ideal number of children. We expected to find that both of these processes affected the upper and the middle classes first. Our finding that the real elite (the highest group comprising about $3 \%$ of the population) had lower fertility than the other groups in 1880, and that the upper-middle class (lower managers and professionals) followed their lead in 1890-1900; may be taken as an indication of the importance of innovation-diffusion factors, as the need for economic adjustment should not have been too pressing among the elite group, for whom the opportunity costs of childbearing would have been low due to their low rates of female labor force participation and their high material standard of living, which would have entailed both spacious housing and the help of domestic servants. It may well have been the case that new attitudes toward birth control developed and spread through society, affecting the behavior of the most affluent groups first, and the behavior of the middle classes later.

The low fertility of the middle class after the transition seems to be attributable to a trade-off between the quantity and the quality of children. After we controlled for female employment and spatial differences, these groups still had low fertility; most likely because they had high educational aspirations for their children, which meant that they could not afford to have a large number of children. This led them to lower their fertility levels below those of both the higher status and the lower status groups. The rather high fertility levels of the elite in this period may in part have been a consequence of their high income levels, which lowered the relative price of having children. But it may also have been an indication of the early adoption of new, more fertility-prone behavior.

In conclusion, our analysis has shown that social class clearly mattered for the course of the fertility transition, and that it continued to matter in the post-transition period. These class differences cannot fully be explained by differences in female labor force participation or residential patterns. Instead, they most likely reflect other economic realities of families in these groups, as well as possible differences in attitudes and norms surrounding childbearing, which combined to produce quite dramatic differences in the number of children born to these families. Determining which of the possible explanations were most important in producing these class differences is beyond the scope of this article, as we would require much more detailed data to investigate this question. 


\section{Acknowledgements}

This work is part of the project "Towards the modern family. Socioeconomic stratification, family formation and fertility in a historical perspective," funded by the Swedish Research Council and the Crafoord Foundation. Previous versions were presented at the IUSSP seminar Socio-economic stratification and fertility before, during and after the demographic transition, Alghero, Italy, 27-29 September 2012 and at the SSHA, Vancouver, Canada, November 2012. We are grateful to the seminar participants and to two anonymous referees for their valuable comments and suggestions. 


\section{References}

Bailey, M.J. (2010). Momma's got the pill: How Anthony Comstock and Griswold v. Connecticut shaped U.S childbearing. American Economic Review 100(1): 98-129. doi:10.1257/aer.100.1.98.

Barnes, G.A. and Guinnane, T.W. (2012). Social class and the fertility transition: a critical comment on the statistical results reported in Simon Szreter's Fertility, class and gender in Britain, 1860-1940. Economic History Review 65(4): 1267-1279. doi:10.1111/j.1468-0289.2011.00631.x.

Becker, G.S. (1991). A treatise on the family. Cambridge, MA: Harvard University Press.

Becker, S.O., Cinnirella, F., and Woessmann, L. (2010). The trade-off between fertility and education: evidence from before the demographic transition. Journal of Economic Growth 15(3): 177-204. doi:10.1007/s10887-010-9054-x.

Bengtsson, T. and Dribe, M. (2006). Deliberate control in a natural fertility population: Southern Sweden 1766-1865. Demography 43 (4): 727-746. doi:10.1353/dem. 2006.0030

Bengtsson, T. and Dribe, M. (2011). The late emergence of socioeconomic mortality differentials: a micro-level study of adult mortality in southern Sweden 1815-1968. Explorations in Economic History 48(3): 389-400. doi:10.1016/ j.eeh.2011.05.005.

Bentgsson, T. and Dribe, M. (2014). The historical fertility transition at the micro level: southern Sweden 1815-1839. Demographic Research forthcoming.

Bengtsson, T., Dribe, M., and Svensson, P. (2012). The Scanian Economic Demographic Database: Version 3.0 (Machine-readable database). Lund: Lund University, Centre for Economic Demography.

Boberg-Fazlic, N., Sharp, P., and Weisdorf, J. (2011). Survival of the richest? Social status, fertility and social mobility in England 1541-1824. European Review of Economic History 15(3): 365-392. doi:10.1017/S136149161100013X.

Bras, H., Kok, J., and Mandemakers, K. (2010). Sibship size and status attainment across contexts: Evidence from the Netherlands, 1840-1925. Demographic Research 23(4): 73-104. doi:10.4054/DemRes.2010.23.4. 
Brown, J.C. and Guinnane, T.W. (2002). Fertility transition in a rural, Catholic population: Bavaria, 1880-1910. Population Studies 56(1): 35-50. doi:10.1080/ 00324720213799.

Cameron, A.C. and Trevedi, P.K. (2009). Microeconometrics using Stata. College Station, TX: Stata Press.

Carlsson, G. (1966). The decline of fertility: innovation or adjustment process. Population Studies 20(2): 149-174.

Christen, P. (2008). Febrl - A freely available record linkage system with a graphical user interface. In: Warren, J.R., Yu, P., Yearwood, J. and Patrick, J.D. (eds.). Proceedings of the second Australasian workshop on health data and knowledge management. Darlinghurst, Australia: Australian Computer Society, Inc: 17-25.

Clark, G. (2007). A farewell to alms. A brief economic history of the world. Princeton: Princeton University Press.

Clark, G. and Cummins, N. (2009). Urbanization, mortality, and fertility in Malthusian England. American Economic Review: Papers \& Proceedings 99(2): 242-247. doi:10.1257/aer.99.2.242.

Clark, G. and Hamilton, G. (2006). Survival of the richest: the Malthusian mechanism in pre-industrial England. Journal of Economic History 66(3): 707-736. doi:10.1017/S0022050706000301.

Cleland, J. (2001). Potatoes and pills: An overview of innovation-diffusion contributions to explanations of fertility decline. In: Casterline, J. (ed.). Diffusion processes and fertility transition: selected perspectives. Washington, D.C.: National Research Council: 39-65.

Cleland, J.R. and Wilson, C. (1987). Demand theories of the fertility transition: An iconoclastic view. Population Studies 41(1): 5-30. doi:10.1080/0032472031 000142516.

Coale, A.J. (1973). The demographic transition reconsidered. International Population Conference, Liège, 1973, vol. 1. Liège: International Union for the Scientific Study of Population.

Coale, A.J. and Trussel, J.T. (1974). Model fertility schedules: variations in the age schedule of childbearing in human populations. Population Index 40(2): 185-258. doi:10.2307/2733910. 
Coale, A.J. and Trussel, J.T. (1978). Technical note: finding the two parameters that specify a model schedule of marital fertility. Population Index 44(2): 203-213. doi:10.2307/2735537.

Coale, A.J. and Watkins, S.C. (eds.) (1986). The decline of fertility in Europe. Princeton: Princeton University Press.

Crafts, N.F.R. (1984). A time series study of fertility in England and Wales, 1877-1938. Journal of European Economic History 13(3): 571-590.

Cummins, N. (2013). Marital fertility and wealth during the fertility transition: rural France, 1750-1850. Economic History Review 66(2): 449-476. doi:10.1111/ j.1468-0289.2012.00666.x.

David, P.A. and Sanderson, W.C. (1986). Rudimentary contraceptive methods and the American transition to marital fertility control, 1855-1915. In: Engerman, S.L. and Gallman, R.E. (eds.). Long-term factors in American economic growth. Chicago: The University of Chicago Press: 307-390.

Doepke, M. (2005). Child mortality and fertility decline: Does the Barro-Becker model fit the facts? Journal of Population Economics 18(2): 337-366. doi:10.1007/ s00148-004-0208-z.

Dribe, M. (2009). Demand and supply factors in the fertility transition: a county-level analysis of age-specific marital fertility in Sweden, 1880-1930. European Review of Economic History 13(1): 65-94. doi:10.1017/S1361491608002372.

Dribe, M. and Scalone, F. (2010). Detecting deliberate fertility control in pretransitional populations: Evidence from six German villages, 1766-1863. European Journal of Population 26(4): 411-434. doi:10.1007/s10680-0109208-8.

Dyson, T. (2010). Population and development. The demographic transition. London: Zed Books.

Easterlin, R.A. and Crimmins, E.M. (1985). The fertility revolution: A supply-demand analysis. Chicago: University of Chicago Press.

Edin, K.A. and Hutchinson, E.P. (1935). Studies of differential fertility in Sweden. London: P.S. King \& Sons.

Erikson, R. and Goldthorpe, J.H. (1992). The constant flux: A study of class mobility in industrial societies. Oxford: Clarendon Press. 
Erikson, R., Goldthorpe, J.H., and Portocarero, L. (1979). Intergenerational class mobility in three Western European societies: England, France and Sweden. British Journal of Sociology 30(4): 415-441. doi:10.2307/589632.

Frykman, J. and Löfgren, O. (1987). Culture builders: A historical anthropology of middle-class life. New Brunswick: Rutgers University Press.

Galloway, P.R., Hammel, E.A., and Lee, R.D. (1994). Fertility decline in Prussia, 1875-1910: a pooled cross-section time series analysis. Population Studies 48(1): 135-181. doi:10.1080/0032472031000147516.

Galloway, P.R., Lee, R.D., and Hammel, E.A. (1998). Infant mortality and the fertility transition: Macro evidence from Europe and new findings from Prussia. In: Montgomery, M.R. and Cohen, B. (eds.). From death to birth: mortality and reproductive change. Washington D.C.: National Research Council: 182-226.

Galor, O. (2005). From stagnation to growth: Unified growth theory. In: Aghion, P. and Durlauf, S.N. (eds.). Handbook of Economic Growth, Volume 1A. Amsterdam: Elsevier: 171-293. doi:10.1016/S1574-0684(05)01004-X.

Garrett, E., Reid, A., Schürer, K., and Szreter, S. (2001). Changing family size in England and Wales. Place, class and demography, 1891-1911. Cambridge: Cambridge University Press. doi:10.1017/CBO9780511495816.

Gaunt, D. (1973). Family planning and the pre-industrial society: some Swedish evidence. In: Ågren, K., Gaunt, D., Erikson, I., Rogers, J., Norberg, A., and Åker, S. (eds.). Aristocrats, farmers and proletarians. Essays in Swedish demographic history. Uppsala: Esselte: 28-59.

Goldin, C. and Katz, L.F. (2002). The power of the pill: Contraceptives and women's career and marriage decisions. Journal of Political Economy 110(4): 730-770. doi:10.1086/340778.

Guinnane, T.W. (2011). The historical fertility transition: A guide for economists. Journal of Economic Literature 49(3): 589-614. doi:10.1257/jel.49.3.589.

Haines, M.R. (1992). Occupation and social class during fertility decline: historical perspectives. In: Gillis, J.R., Tilly, L.A., and Levine, D. (eds.). The European experience of changing fertility. Cambridge, MA: Blackwell: 193-226.

Haines, M.R. (1998). The relationship between infant and child mortality and fertility: Some historical and contemporary evidence for the United States. In: Montgomery, M.R. and Cohen, B. (eds.). From death to birth: mortality and reproductive change . Washington D.C.: National Research Council: 227-253. 
Henry, L. (1961). Some data on natural fertility. Eugenics Quarterly 8(2): 81-91.

Hofsten, E. and Lundström, H. (1976). Swedish population history: Main trends from 1750 to 1970. Stockholm: SCB/Liber.

Lesthaeghe, R. and Vanderhoeft, C. (2001). Ready, willing, and able: A conceptualization of transitions to new behavioral forms. In: Casterline, J. (ed.). Diffusion Processes and Fertility Transition: Selected Perspectives. Washington, D.C.: National Research Council: 240-264.

Livi-Bacci, M. (1986). Social-group forerunners of fertility control in Europe. In: Coale, A.J. and Watkins, S.C (eds.). The decline of fertility in Europe. Princeton: Princeton University Press: 182-200.

Long, J.S. (1997). Regression models for categorical and limited dependent variables. Thousand Oaks, CA: Sage.

Knodel, J. and van de Walle, E. (1979). Lessons from the past: Policy implications of historical fertility studies. Population and Development Review 5(2): 217-145. doi:10.2307/1971824.

Maas, I. (2000). Recode from HISCO to EGP [Unpublished manuscript]. Utrecht: University of Utrecht.

Mosk, C. (1983). Patriarchy and fertility: Japan and Sweden, 1880-1960. New York: Academic Press.

Reher, D. (1999). Back to the basics: Mortality and fertility interactions during the demographic transition. Continuity and Change 14(1): 9-31. doi:10.1017/S0268416099003240.

Reher, D.S. and Sanz-Gimeno, A. (2007). Rethinking historical reproductive change: Insights from longitudinal data for a Spanish town. Population and Development Review 33(4): 703-727. doi:10.1111/j.1728-4457.2007.00194.x.

Ruggles, S., Roberts, E., Sarkar, S., and Sobek, M. (2011). The North Atlantic Population Project: Progress and prospects. Historical Methods 44(1): 1-6. doi:10.1080/01615440.2010.515377.

Santow, G. (1995). Coitus interruptus and the control of natural fertility. Population Studies 49(1): 19-43. doi:10.1080/0032472031000148226.

Scalone, F. and Dribe, M. (2012). Socioeconomic status and net fertility in the demographic transition: Sweden in 1900 - A preliminary analysis. Popolazione e Storia 2010(2): 111-132. 
Schneider, J.C. and Schneider, P.T. (1996). Festival of the poor. Fertility decline and the ideology of class in Sicily 1860-1980. Tucson, AZ: The University of Arizona Press.

Schultz, T.P. (1985). Changing world prices, women's wages, and the fertility transition: Sweden, 1860-1910. Journal of Political Economy 93(6): 1126-1154. doi:10.1086/261353.

Shyrock, H.S. and Siegel, J.S. (1980). The methods and materials of demography. Washington, D.C.: Department of Commerce, Bureau of the Census.

Silenstam, P. (1970). Arbetskraftsutbudets utveckling i Sverige 1870-1965. Stockholm: IUI.

Skirbekk, V. (2008). Fertility trends by social status. Demographic Research 18(5): 145-180. doi:10.4054/DemRes.2008.18.5.

Sobek, M., Cleveland, L., Flood, S., Hall, P.K., King, M.L., Ruggles, S., and Schroeder, M. (2011). Big data: Large-scale historical infrastructure from the Minnesota Population Center. Historical Methods 44(2): 61-68. doi:10.1080/01615440. 2011.564572.

Sogner, S., Randsborg, H.B., and Fure, E. (1984). Fra stua full til tobarnskull. Oslo: Universitetsforlaget.

Stanfors, M. (2003). Education, labor force participation and changing fertility patterns. A study of women and socio-economic change in twentieth century Sweden. Stockholm: Almqvist \& Wiksell International.

Szreter, S. (1996). Fertility, class and gender in Britain 1860-1940. Cambridge: Cambridge University Press. doi:10.1017/CBO9780511582240.

Thålin, M. (2007). Class clues. European Sociological Review 23(5): 557-572. doi:10.1093/esr/jcm019.

Van Bavel, J. (2004). Deliberate birth spacing before the fertility transition in Europe: Evidence from nineteenth-century Belgium. Population Studies 58(1): 95-107. doi:10.1080/0032472032000167706.

Van Bavel, J. (2006). The effect of fertility limitation on intergenerational social mobility: The quantity-quality trade-off during the demographic transition. Journal of Biosocial Science 38(4): 553-569. doi:10.1017/S0021932005026994.

Van Bavel, J., Moreels, S., van de Putte, B., and Matthijs, K. (2011). Family size and intergenerational social mobility during the fertility transition: Evidence of 
Dribe \& Scalone: Social class and net fertility before, during, and after the demographic transition

resource dilution from the city of Antwerp in nineteenth century Belgium. Demographic Research 24(14): 313-344. doi:10.4054/DemRes.2011.24.14.

Van de Putte, B. (2007). The influence of modern city life on marriage in Ghent at the turn of the twentieth century: Cultural struggle and social differentiation in demographic behavior. Journal of Family History 32(4): 433-458. doi:10.1177/0363199007305765.

Van de Putte, B. and Miles, A. (2005). A social classification scheme of historical occupational data. Partner selection and industrialism in Belgium and England, 1800-1918. Historical Methods 38(2): 61-94.

Van Leeuwen, M.H.D. and Maas, I. (2010). Historical studies of social mobility and stratification. Annual Review of Sociology 36(1): 429-451. doi:10.1146/ annurev.soc.012809.102635.

Van Leeuwen, M.H.D. and Maas, I. (2011). HISCLASS. A historical international social class scheme. Leuven: Leuven University Press.

Van Leeuwen, M.H.D., Maas, I., and Miles, A. (2002). HISCO. Historical international standard classification of occupations. Leuven: Leuven University Press.

Wahl, J.B. (1992). Trading quantity for quality. Explaining the decline in American fertility in the nineteenth century. In: Goldin, C. and Rockoff, H. (eds.). Strategic factors in nineteenth century American economic history. A volume to honor Robert W. Fogel. Chicago: The University of Chicago Press: 375-397.

Wohlin, N. (1915). Den äktenskapliga fruktsamhetens tillbakagång på Gotland. Stockholm: Nordiska bokhandeln.

Woods, R. (2000). The demography of Victorian England and Wales. Cambridge: Cambridge University Press. doi:10.1017/CBO9780511496127. 


\section{Appendix. A comparison of CWR and mortality-adjusted CWR.}

The marital CWR has been defined as the number of children aged 0-4 per 1,000 married women aged 15-54 (Shryock and Siegel 1980). It is easy to see that the children under age five may have been born during the five-year period before the census date, when the women were up to five years younger.

$$
C W R=\frac{P_{0-4}}{P_{f 15-54}} \times 1000
$$

It is possible to adjust the CWRs by taking mortality into account. Dividing the estimated number of births in the previous five years by the estimated amount of women 2.5 years before the census time, the adjusted $\mathrm{CWR}_{0-4}$ is:

$$
\text { adj. } C W R=\frac{P_{0-4} \times\left(\frac{500000}{L_{0-4}}\right)}{\left[\left(P_{f 20-59} \times\left(\frac{L_{15-54}}{L_{20-59}}\right)+P_{f 15-54}\right] \times 0.5\right.}
$$

This adjustment can be used to test the influence of socioeconomic mortality differentials on estimates of net fertility (standard CWR). To do this we need SES- and age-specific mortality rates, which are not available for Sweden as a whole at the time under consideration. We have therefore constructed a sensitivity analysis of three different regions for which this information is available: Malmöhus county, Västerbotten county, and Stockholm city. The mortality data came from five parishes in Malmöhus county (The Scanian Economic-Demographic Database, Bengtsson, Dribe, and Svensson 2012), the parish of Skellefteå in Västerbotten county (The Demographic Database, Umeå University), and the city of Stockholm (The Roteman Archive). ${ }^{5}$ Based on the mortality data and the county-level CWR, we calculated the adjusted CWR.

The SES- and the age-specific mortality rates were calculated for the period 1890-1900 and then compared to the CWR in 1900. In order to reduce problems of random variation in the mortality data, we did the calculations using a condensed HISCLASS scheme which had five classes: elite (HICLASS 1-5), skilled workers (HISCLASS 6, 7 and 9), farmers (HISCLASS 8), farm workers (HISCLASS 10, 12), and unskilled workers (HISCLASS 11).

Figure A.1 shows the unadjusted marital CWRs compared to two different adjusted marital CWRs. The CWRs were corrected by adopting the age-specific mortality rates of the corresponding social class. Looking at Figure A.1, it is clear that

${ }^{5}$ We are grateful to Göran Broström, Sören Edvinsson, and Joseph Molitoris for providing the data needed to do these calculations. 
the fertility pattern by socioeconomic status did not change regardless of the mortality model we adopted. Obviously, the mortality correction had some effects, but not enough to change the basic fertility pattern by socioeconomic status. These results clearly show that in Sweden at the end of the 19th century, differences in the number of living children per women explained most of the socioeconomic differences in net fertility, whereas the socioeconomic differences in mortality seem to have had only a limited role. In other words, the discussion in the article on class differences in net fertility generally applies to the patterns for marital fertility as well.

Figure A1: Marital CWR and mortality-adjusted CWR for Malmöhus county, Västerbotten county and Stockholm city in 1900 (per 1,000 women)

A. Malmöhus county

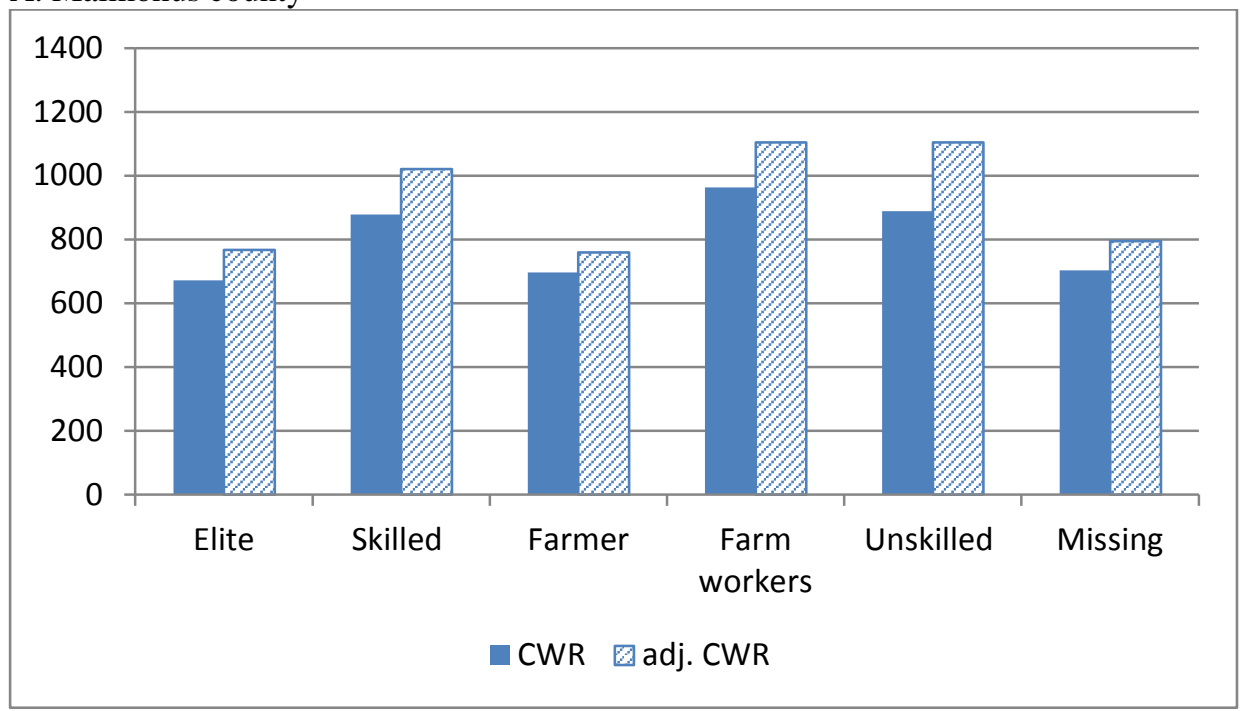

Source: The Scanian Demographic Database (Bengtsson, Dribe and Svensson 2012) and SweCens, see Table 1. 
B. Stockholm city

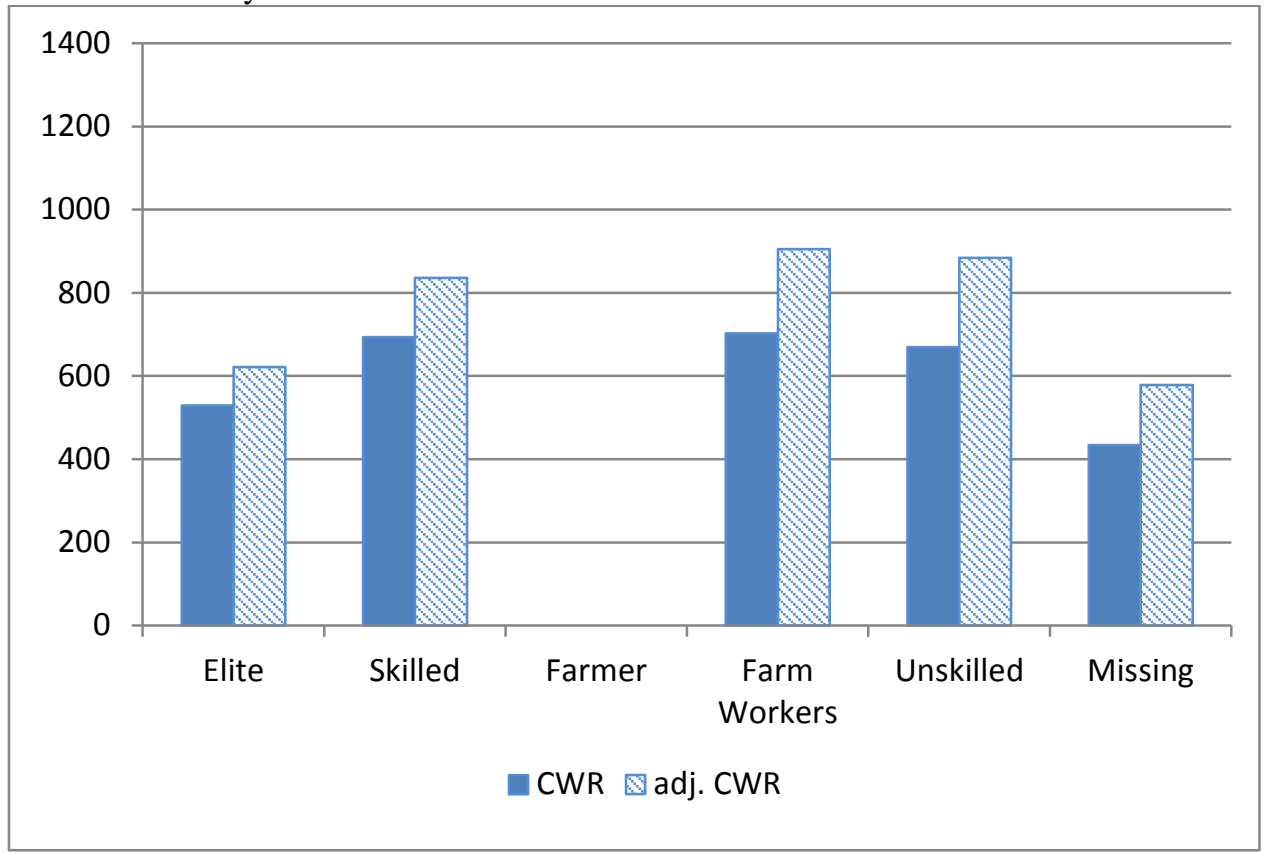

Source: The Roteman's Archive and SweCens, see Table 1. 
Dribe \& Scalone: Social class and net fertility before, during, and after the demographic transition

C. Västerbotten county

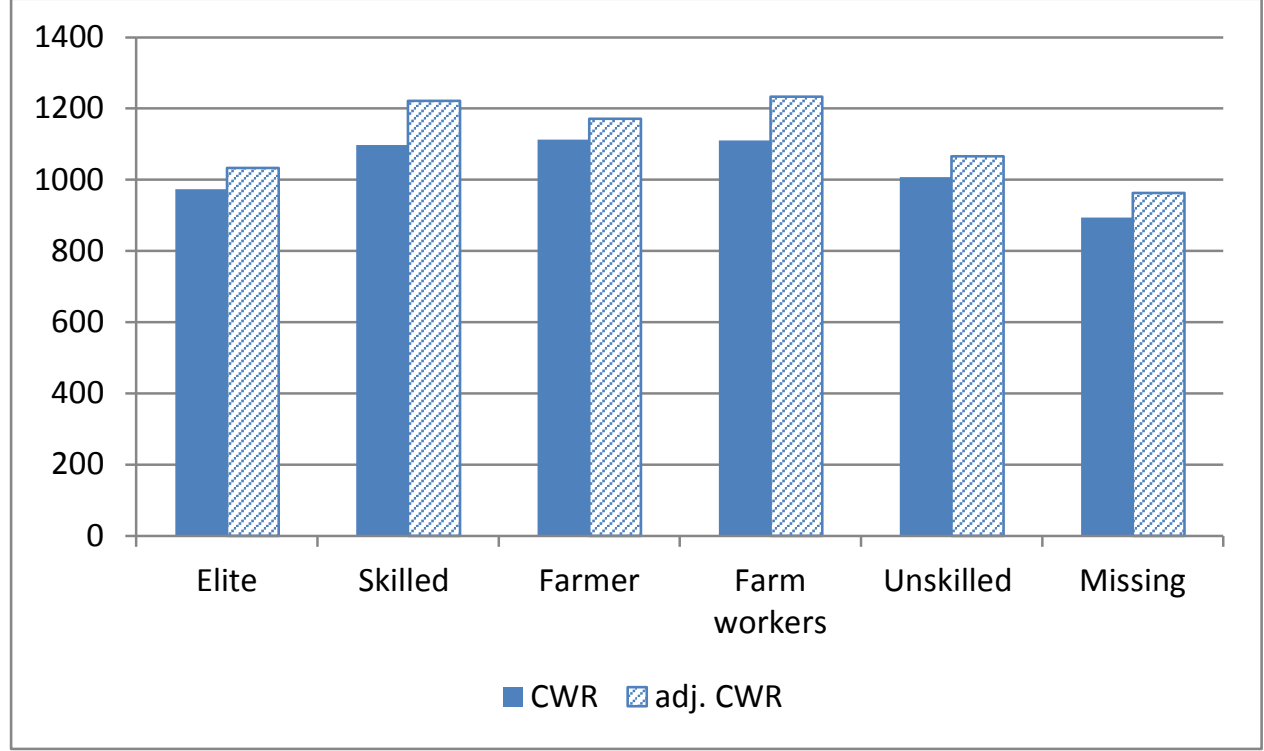

Source: The Demographic Database, Umeå University and SweCens, see Table 1. 